\title{
Evaluation of composite resin microleakage with using different bonding agents by micro
} computed tomography

\begin{abstract}
Pinar Khalis Bilal ${ }^{(1)}$, Diyar Khalid Bakr ${ }^{(2)}$
Background and objectives: Microleakage is the major challenge in resin-based restorations. The aim of the study was to determine the amount of the microleakage for different adhesive systems with micro computed tomography.

Material and methods: Thirty extracted human premolars have been used, by preparing standardized class $V$ cavities. Thirty premolars divided into 3 groups of each 10 specimens. In group A; One up bond F plus, Tokuyama dentals ( $6^{\text {th }}$ generation), group B; Palfique bond, Tokuyama dentals ( $7^{\text {th }}$ generation), and group C; Palfique universal bond, Tokuyama dentals ( $8^{\text {th }}$ generation) adhesive systems have been used. Palfique LX5, Tokuyama dentals composite resin used for restoration of cavities. After the specimens undergone thermocycling process (1000 cycles), immersed into the silver nitrate solution after the specimens being varnished by nail polish. Micro computed tomography scanning done for each specimen. Statistical analysis undergone by using descriptive statistic, one-way ANOVA and least significant difference (LSD) tests.

Results: Group C; Palfique universal bond ( $8^{\text {th }}$ generation) showed the least amount of microleakage followed by group $B$; Palfique bond ( $7^{\text {th }}$ generation) adhesive systems; while group $A$; one up bond $F$ plus ( $6^{\text {th }}$ generation) adhesive system showed maximum amount of microleakage. Furthermore, there was a significant difference between group $A$; one up bond $\mathrm{F}$ plus ( $6^{\text {th }}$ generation) and group; $C$ Palfique universal bond ( $8^{\text {th }}$ generation) adhesive systems.

Conclusion: Newer adhesive systems have better success achievements and recommended to be used in practical bases.
\end{abstract}

Keywords: Micro computed tomography, bonding agents, adhesion, class $\mathrm{V}$, microleakage.

\footnotetext{
${ }^{(1)}$ College of Dentistry, Tishk International University, Erbil, Iraq.

${ }^{(2)}$ College of Dentistry, Hawler Medical University, Erbil, Iraq.

Correspondent name: Pinar Khalis Bilal

Email: bnarkhalis93@gmail.com
}

\section{Introduction}

Currently composite resins are the main materials used in restorations, since there are many innovations and improvements such as use of different novel particles with lowshrinkage monomers. We find impressive rise in use of bonded composite restorations with great success. ${ }^{1}$

In the beginning of the era of restorative dentistry, retentions, resistance and stability of the restorations required excess remove of sound tooth structure to create undercuts to aid in retention. Nowadays, this problem mainly solved by introduction of newer generation, dentin-bonding agents. ${ }^{2}$

Dental adhesive generations through years underwent several changes in their chemistry, mechanism, strength, number of steps, application techniques and clinical effectiveness. When self-etching system compared with etch-and-rinse system, it has several advantages; self-etching adhesives is a less technique sensitive method, causes less post-operative pain, and leave hydroxyapatite crystals available for chemical bonding of functional monomers to calcium, 
which may contribute to interface stability.

After introducing of self-etch system that gave the advantage of eliminating acid etching step by mixing acid and prime, the system has the strategy of superficially demineralize dentin and simultaneously penetrate it with monomers, and it was also remained strong enough $\mathrm{tt}$

$(23 \mathrm{MPa})$. This system came in $6^{\text {th }}$ generation bonding agents. 5,2

After that one-step self-etching adhesive system introduced which combine acid etcher, primer and adhesive in one bottle. This made the practical work less technique sensitive and reduced time consuming and it comes as $7^{\text {th }}$ generation bonding agent. ${ }^{4,5}$

Currently the newest system is light- and self-cured bonding agent came as $8^{\text {th }}$ generation dentin bonding agent. By eliminating light cure step it also adds the advantage of time saving and prevents solvents evaporation. ${ }^{5,6}$

Within previous years, many techniques have been used in order to evaluate microleakage; which occurs as a result of external invasion through the restoration margins by penetration or movement of bacteria, fluids, molecules and ions into the tooth-resin interface. The majorities were using dye penetration technique. In which the main disadvantage of this technique is that it only provides a qualitative assessment, namely, confirmation of the presence or absence of the dye in the particular section studied. Due to this reason, it makes the test not to be relied on and consequently it is important to develop new methods to accurately quantify interfacial leakage. $^{7-11}$

$\mathrm{X}$-ray micro-computed tomography (microCT) most recently developed and used in evaluation of microleakage and gap formation in resin based restorations. Micro CT reconstructs 3D images of entire dental restorations and dental tissues. In this method the specimens need to be immersed in a solution like silver nitrate which has radiopacity higher than dental tissues in order the micro CT differentiates between the dental tissue, resin composite material and produced gap and leakage between the resin-dentine interface. ${ }^{12-14}$
Microleakage was always been the major problem with the composite resin restorations. Thus, this study was aimed to determine the microleakage of the $6^{\text {th }}, 7^{\text {th }}$, and $8^{\text {th }}$ generation dentin bonding agents by evaluating them with micro computed tomography.

\section{Methods}

Sample selection. Thirty intact human premolar teeth, extracted for orthodontic purpose, have been collected within three months. The teeth collected from the patients ranged from 15 to 25 years old. The teeth debrided of blood, saliva, then scaled, polished, and examined under a magnification of $3 \times$ using the surgical loupes and stereomicroscope to eliminate any cracks. Among 60 collected teeth according to the inclusion and exclusion criteria 30 of them have been chosen for the study.

After that specimens kept in distilled water at $4^{\circ} \mathrm{C}$ up to 3 months in order to keep the specimens hydrated. Moreover, every week the samples washed and distilled water renewed in order to avoid bacterial growth and minimize deterioration according to International Standardization Organization, TS 11405 for testing of adhesion to tooth structure. $^{15}$

Cavity preparation. Class V cavities have been prepared located $1 \mathrm{~mm}$ above the cement-enamel junction (CEJ). Standardized box shaped class V cavities with a uniform mesio-distal extension of 3 $\mathrm{mm}$, occluso-cervical length of $2 \mathrm{~mm}$ and depth of $2 \mathrm{~mm}$ were prepared with a round tungsten diamond bur, the walls aligned by fissure diamond bur and finishing done by fine round and fissure diamond bur with a high speed hand-piece with air/water spray. All the dimensions were evaluated using a digital sliding caliper and a periodontal probe.

The total of 30 teeth have divided into 3 groups of each 10 specimen (Figure 1) A; One up bond $\mathrm{F}$ plus, $6^{\text {th }}$ generation bonding agent, B; Palfique bond, $7^{\text {th }}$ generation bonding agent, and $\mathrm{C}$; Palfique universal bond, $8^{\text {th }}$ generation bonding agent of Tokuyama dentals cooperation, (Table 1) shows the sample grouping. 


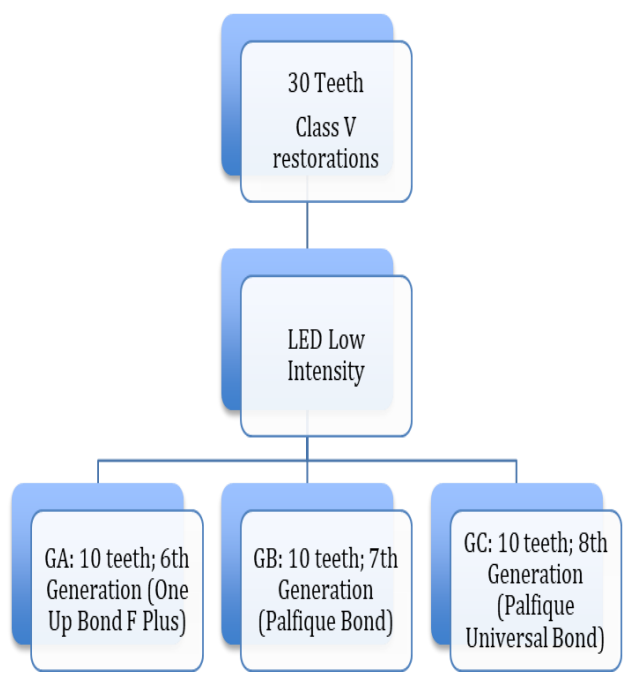

Figure 1: A schematic diagram showing sample grouping.

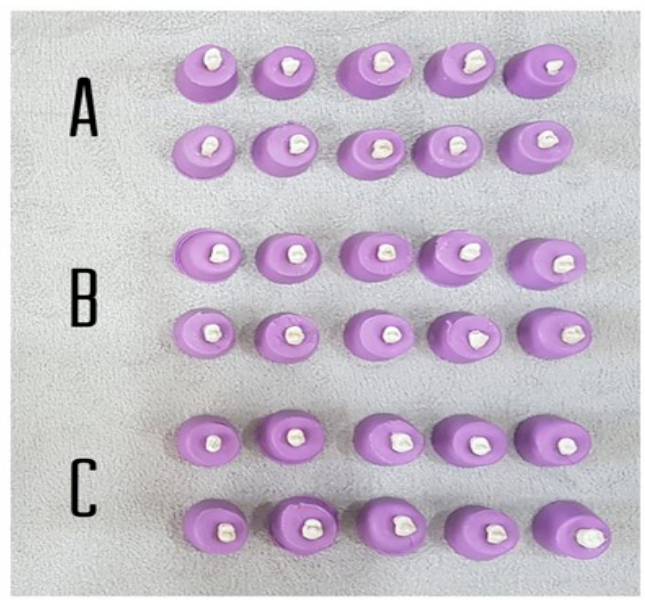

Figure 2: Photo shows that each group with 10 specimens.

Sample Preparations. In Group A: One up bond $\mathrm{F}$ plus, $6^{\text {th }}$ generation light-cured, self-etching adhesive system; in group B: Palfique bond 'self etching' single step $7^{\text {th }}$ generation adhesive system; and in group $\mathrm{C}$ : Palfique universal bond 'Self cured $8^{\text {th }}$ generation single step universal adhesive of "Tokuyama Dentals" have been used (Table 2 and figure 2) and applied according to the manufacturer's instructions.

After applying bonding agents to all three groups, the cavities restored by Palfique LX5 resin-based dental restorative material of "Tokuyama Dentals" (Figure 2) with A2 shade according to the manufacturers instructions. In all three groups Zenolite LED curing light unit have been used.
Table 1: Schematic representation of the materials used in the study.

\begin{tabular}{|c|c|c|}
\hline Groups & $\begin{array}{c}\text { Generations of } \\
\text { adhesives }\end{array}$ & Materials used ' \\
\hline A. 10 specimen & $6^{\text {th }}$ Generation & $\begin{array}{c}\text { One-Up Bond F } \\
\text { Plus, Tokuyama } \\
\text { Dentals }\end{array}$ \\
\hline B. 10 specimen & $7^{\text {th }}$ Generation & $\begin{array}{c}\text { Palfique Bond, } \\
\text { Tokuyama Den- } \\
\text { tals }\end{array}$ \\
\hline C. 10 specimen & $8^{\text {th }}$ Generation & $\begin{array}{c}\text { Palfique Univer- } \\
\text { sal Bond, To- } \\
\text { kuyama Dentals }\end{array}$ \\
\hline
\end{tabular}

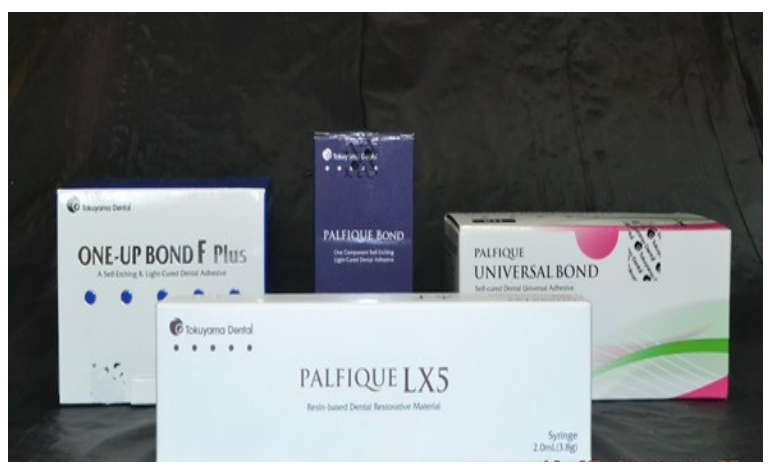

Figure 3: Bonding agents and composite resin used in the studycomposite resin used in the study

Thermo-cycling procedure. All the specimens from each group wrapped with socks and ordered from 1 to 10 , and also on each samples its number had written. Then all 3 groups of 30 total teeth put into one single sock and put into SD Mechatronik Thermocycler machine (Figure 3). Specimens thermo-cycled in distilled water for 1000 cycles $\left(5-55^{\circ} \mathrm{C}\right)$ with dwell time of $30 \mathrm{~s}$ and draining time of $10 \mathrm{~s}$ between cycles.

After thermocycling all the samples varnished with nail polish, leaving $1 \mathrm{~mm}$ around the restoration area in order $\mathrm{AgNo}^{3}$ solution (Figure 4) could penetrate into the resin-tooth interface. The specimens ordered in number by coloring each sample with a different nail varnish color from 1 to 10. Then samples of each group immersed into $50 \% \mathrm{AgNO}^{3}$ solution for 12 hours. Furthermore specimens rinsed and washed, finally got ready for scanning. 


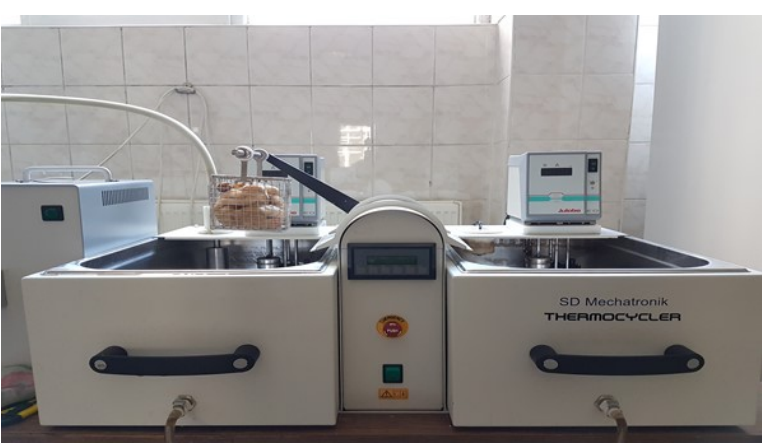

Figure 4: SD Mechatronik Thermocycler machine used in the study.

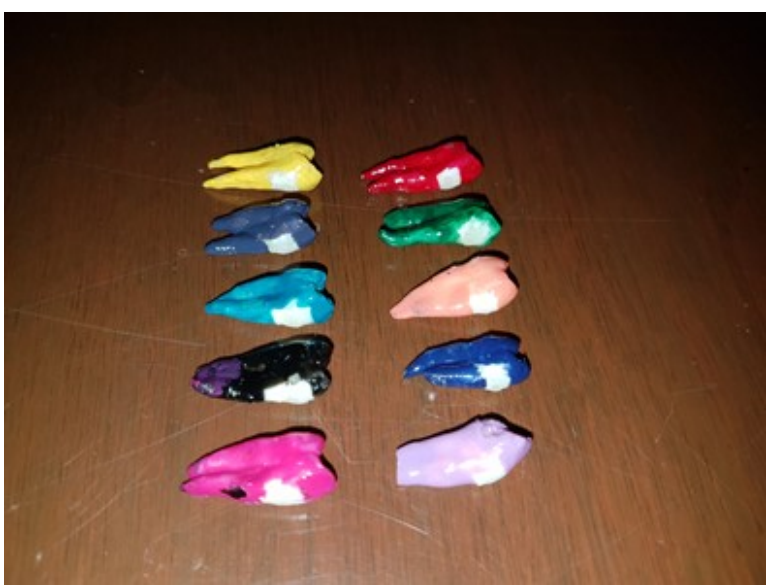

Figure 5: Samples of each group varnished with nail polish leaving one $\mathrm{mm}$ around the restoration.

\section{Micro-CT analysis.}

Micro-leakage analysis performed by using Sedecal/ Super Argus micro-tomography system (Figure 5 and 6), and visualized by VISTA_CT (4.12 Build 746) software program. The scanning done in high resolution with 2 shots of 360 projections having 1040 radial pixel projection size $(\mathrm{x})$ and 1144 axial pixel projection size (z), with 3 bed positions.

The data acquired with two-dimensional images processed into cross-sectional images (Axial, transverse and sagittal). The pattern of infiltration digitally assessed with a dedicated computer software system, which will allow observing of all micro scans and detecting the leakage of silver nitrate "AgNO3". Three-dimensional 3D images obtained by juxtaposition of 2D images of adjacent slices. Since the beginning and the end of the procedure, micro-leakage could be observed in each scan and the infiltration was measured with the accuracy up to $0.001 \mathrm{~mm}$.

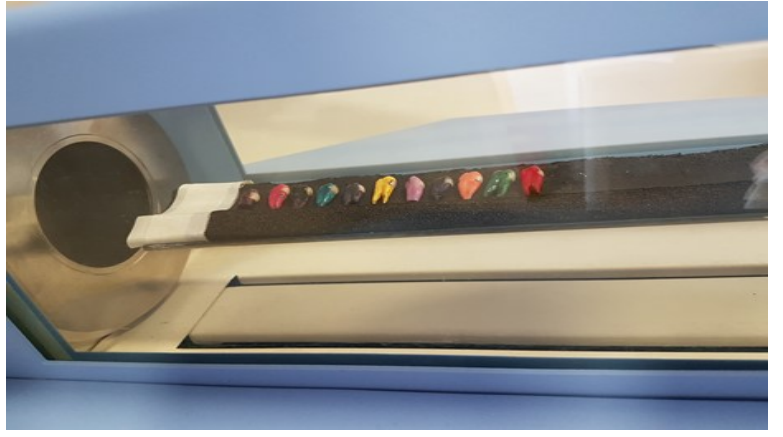

Figure 6: Samples placed for scanning into the machine

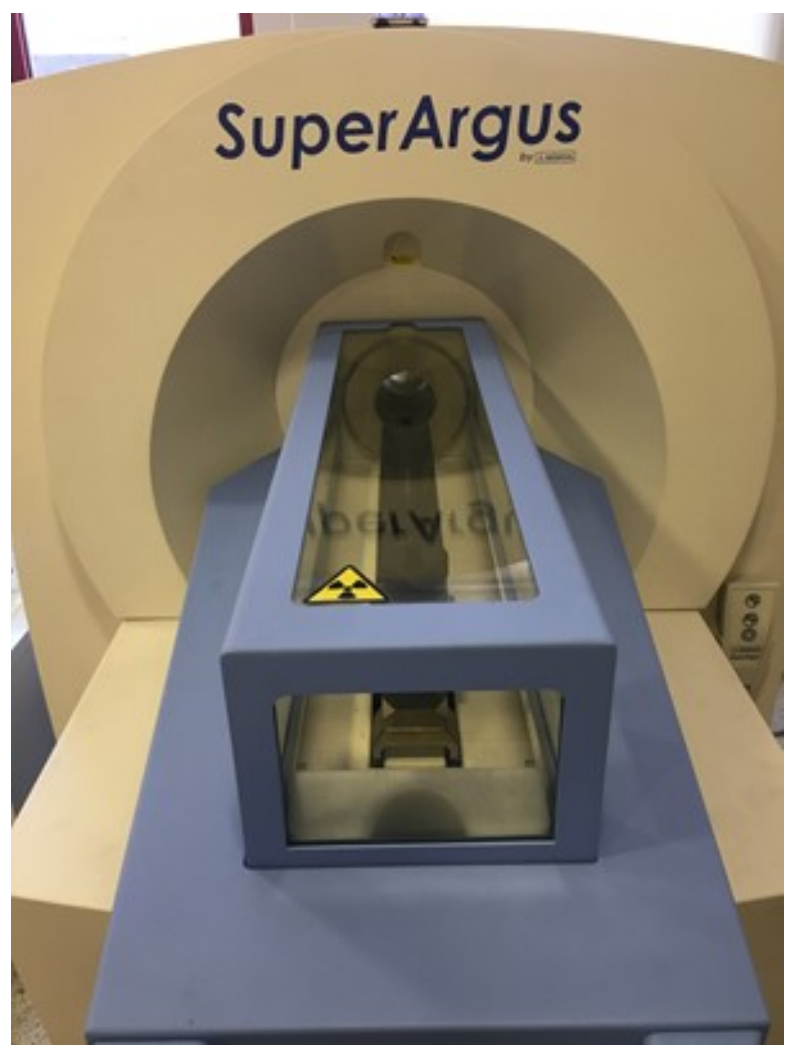

Figure 7: Sedecal/ Super Argus micro-tomography machine

Statistical Analysis. Descriptive statistic and one-way ANOVA with least significant difference (LSD) tests were used. ANOVA was used to compare between groups and LSD test was used for post hoc analysis. All statistical interferences are made within a $95 \%$ confidence interval.

\section{Results}

The obtained records were evaluated on the basis of the results analyzed from $\mathrm{AgNO} 3$ infiltration within the samples (Figure 7), which were aimed to study the microleakage infiltration within the enamel, and they were expressed in $\mathrm{mm}$. In the 
current study three bonding system have been used (one up bond $\mathrm{F}$ plus $6^{\text {th }}$ generation, Palfique bond $7^{\text {th }}$ generations and Palfique universal bond $8^{\text {th }}$ generation) bonding systems, with equal number of samples in each group (10 samples).

According to the descriptive analysis test it showed that One up bond $\mathrm{F}$ plus $\left(6^{\text {th }}\right.$ generation) showed maximum microleakage followed by Palfique bond ( $7^{\text {th }}$ generation) while Palfique bond universal $\left(8^{\text {th }}\right.$ generation) showed minimum microleakage among three groups.

Further analysis was used to determine the differences between three groups, one-way
ANOVA (Table 4) revealed that there was insignificant difference between groups, while the LSD test (Table 5) revealed that there is significant difference between One up bond $\mathrm{F}$ plus $\left(6^{\text {th }}\right.$ generation $)$ and Palfique bond universal $\left(8^{\text {th }}\right.$ generation $)(P<5 \%)$ (0.023).

Further results showed that there is no significant difference between the one up bond $F$ plus $\left(6^{\text {th }}\right.$ generation) and Palfique bond ( $7^{\text {th }}$ generation $)(P<5 \%)(0.362)$, also Palfique bond $\left(7^{\text {th }}\right.$ generation) compared with Palfique bond universal $\left(8^{\text {th }}\right.$ generation) shows non-significant differences too $(\mathrm{P}<5 \%)$.

Table 2: Descriptive statistic test of microleakage between three groups in ( $\mathrm{mm}$ ).

\begin{tabular}{|c|c|c|c|c|c|c|c|c|}
\hline \multirow{2}{*}{ Bonding agents } & \multirow{2}{*}{$\mathbf{N}$} & \multirow{2}{*}{ Mean } & \multirow{2}{*}{$\begin{array}{l}\text { Std. Devia- } \\
\quad \text { tion }\end{array}$} & \multirow{2}{*}{ Std. Error } & \multicolumn{2}{|c|}{$\begin{array}{l}\text { 95\% Confidence Interval } \\
\text { for Mean }\end{array}$} & \multirow{2}{*}{ Minimum } & \multirow{2}{*}{$\begin{array}{l}\text { Maxi- } \\
\text { mum }\end{array}$} \\
\hline & & & & & $\begin{array}{l}\text { Lower } \\
\text { Bound }\end{array}$ & Upper Bound & & \\
\hline One up bond $\mathrm{F}$ plus & 10 & .52890 & .572889 & .181164 & .11908 & .93872 & .121 & 1.559 \\
\hline Palfique bond & 10 & .35900 & .414815 & .131176 & .06226 & .65574 & .003 & 1.230 \\
\hline Palfique bond universal & 10 & .08750 & .065980 & .020865 & .04030 & .13470 & .000 & .175 \\
\hline Total & 30 & .32513 & .436800 & .079748 & .16203 & .48824 & .000 & 1.559 \\
\hline
\end{tabular}
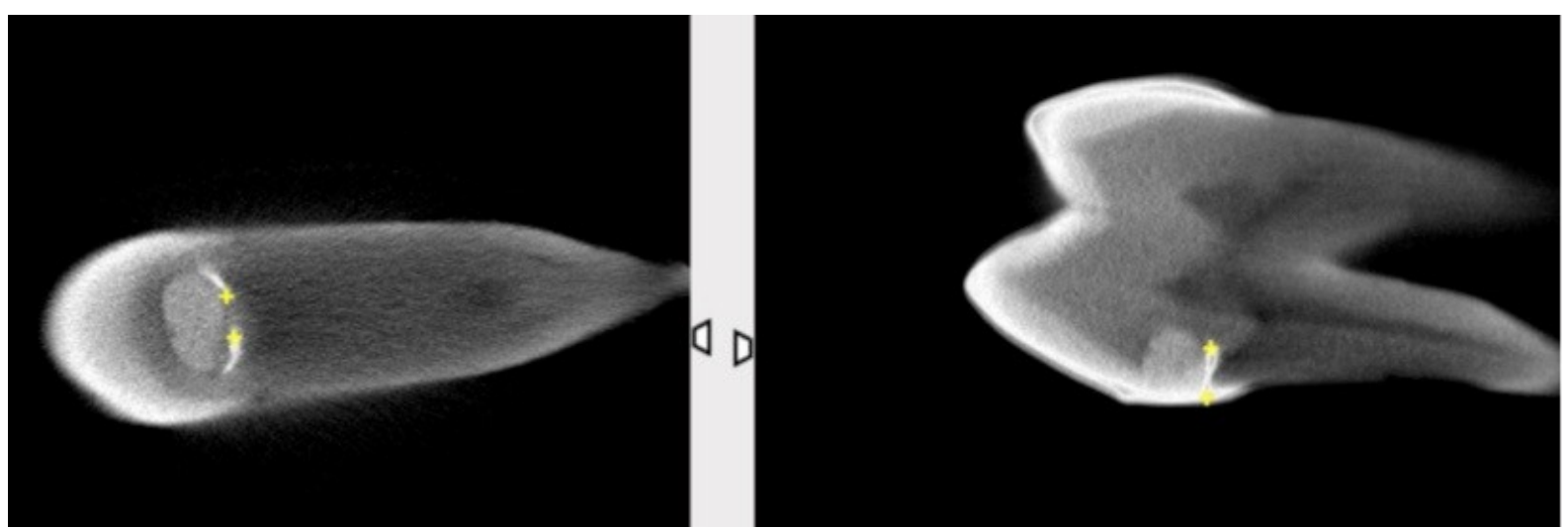

Figure 8: The pattern of AgNO3 infiltration within the specimen. 
Table 3: One-way ANOVA statistical test among three groups for microleakage in (mm).

\begin{tabular}{|c|c|c|c|c|c|}
\hline Bonding & Sum of Squares & df & Mean Square & F & Sig. \\
\hline Between Groups & .991 & 2 & .496 & 2.947 & .070 \\
\hline Within Groups & 4.542 & 27 & .168 & & \\
\hline Total & 5.533 & 29 & & & \\
\hline
\end{tabular}

Table 4: Least Significant difference test: Multiple Comparison test for microleakage between three groups in (mm).

\begin{tabular}{|c|c|c|c|c|c|c|}
\hline \multirow[b]{2}{*}{ (I) Factor } & \multirow[b]{2}{*}{ (J) Factor } & \multirow[b]{2}{*}{ Mean Difference (I-J) } & \multirow[b]{2}{*}{ Std. Error } & \multirow[b]{2}{*}{ Sig. } & \multicolumn{2}{|c|}{ 95\% Confidence Interval } \\
\hline & & & & & Lower Bound & Upper Bound \\
\hline \multirow{2}{*}{ One up bond } & Palfique bond & 169900 & .183417 & .362 & -.20644 & .54624 \\
\hline & $\begin{array}{l}\text { Palfique universal } \\
\text { bond }\end{array}$ & $.441400^{*}$ & 183417 & .023 & .06506 & .81774 \\
\hline \multirow{2}{*}{ Palfique bond } & $\begin{array}{l}\text { One up bond } \mathrm{F} \\
\text { plus }\end{array}$ & -169900 & 183417 & .362 & -.54624 & 20644 \\
\hline & $\begin{array}{l}\text { Palfique universal } \\
\text { bond }\end{array}$ & .271500 & .183417 & .150 & -.10484 & .64784 \\
\hline \multirow{2}{*}{$\begin{array}{l}\text { Palfique universal } \\
\text { bond }\end{array}$} & $\begin{array}{l}\text { One up bond } \mathrm{F} \\
\text { plus }\end{array}$ & $-.441400^{*}$ & .183417 & .023 & -.81774 & -.06506 \\
\hline & Palfique bond & -.271500 & 183417 & .150 & -.64784 & . 10484 \\
\hline
\end{tabular}

*The mean difference is significant at the 0.05 level.

\section{DISCUSSION}

Microleakage have always been the major challenge in resin-based restorations. Studies, developments and newly introduced materials are aimed to overcome and solve the problem. In class $\mathrm{V}$ restorations microleakage is the major problem since it has highest amount of Cfactor 'is the ratio of bonded surface of the restoration to the un-bonded surfaces'.Adhesive systems developed from $1^{\text {st }}$ generation to $8^{\text {th }}$ generation different bonding systems within the years, there have been several studies to evaluate and overcome the problems occurred from different adhesive systems. ${ }^{6}$

In this study three different adhesive systems have been used and evaluated with micro CT in order to compare the amount of leakage in different bonding agents. In 2012 a study done by Poggio et al. and in 2015 another study by Shetty et al. done, in both studies they concluded that self-etch adhesive system has a superior success over total-etch adhesive systems. ${ }^{16,17}$ So, in this study we have compared three self-etch adhesive systems; $6^{\text {th }}$ generation, $7^{\text {th }}$ generation and $8^{\text {th }}$ generation adhesive systems.

In 2016, Somani et al. compared three adhesive systems and found out Xeno $\mathrm{V}$ $\left(7^{\text {th }}\right.$ generation, self-etching, light-cured dental adhesive) have the highest amount of microleakage, followed by FL Bond II $\left(6^{\text {th }}\right.$ generation, self-etching, light-cured dentin bonding agent), and Futurabond DC $\left(8^{\text {th }}\right.$ generation, self-etching, dual-cured dental adhesive) shows the least amount of microleakage, ${ }^{(2)}$

While in this study, microleakage was detected using micro CT technology. As 
reported by Neves et al. in 2014, this technique has shown good sensitivity to evaluate the pattern of silver nitrate infiltration at the resin-tooth interface. ${ }^{(18)}$. In all the three adhesive system materials used in this study showed a degree amount of silver nitrate penetration within the enamel and according to the micro-CT results was possible to record that the highest amount of leakage was $1,55 \mathrm{~mm}$. However, the results showed that group $\mathrm{C} ; 8^{\text {th }}$ generation adhesive system (Palfique universal bond, Tokuyama dentals) observed the least amount of microleakage and it also has a significant $\quad \mathrm{rr}$ difference when compared to the group A; $6^{\text {th }}$ generation (one up bond $\mathrm{F}$ plus) adhesive system, due to the Palfique universal bond's contents of new '3D-SR adhesive monomer' (phosphoric acid monomer) for demineralization of the tooth substance and provides chemical bonding to tooth and the adhesive SR monomer in the bonding material achieves; multiple-point interactions with dentin, three-dimensional crosslinking reactions with calcium ions and three-dimensional crosslinking polymerization. ${ }^{19}$ Also having BoSE technology which uses borate catalyst which has the ability to exhibit high catalyst activity under acidic condition and a thin bonding layer formed after air blow becomes hard due to the rapid progression of polymerization and curing on its adhesive surface when it comes into contact with resin-based materials, and its compatibility with all etching techniques and with dual and self cured composite resins. Additionally, since there is no curing step that avoids the possibility of losing its effectiveness makes this system to have superior results when compared with others. ${ }^{20-22}$

The maximum microleakage shown in $6^{\text {th }}$ generation adhesive system (One up bond $\mathrm{F}$ plus), which is HEMA-free, when compared to the other groups, so the results could be contributed to the absence of HEMA in $6^{\text {th }}$ generation adhesive system (One up bond F plus). Since the hydrophilicity of HEMA makes it an excellent adhesion promoting monomer and by enhancing wetting of dentin it significantly improves bond strength, thereby reducing microleakage. HEMA also generates hydrogen bonds inside the micro-porosities of demineralized dentin, mechanically interlocking into the substrate by undergoing hygroscopic expansion after polymerization, thereby resulting in stronger bonds to the dentin surface, ${ }^{(6)}$ Therefore presence of HEMA makes the $7^{\text {th }}$ generation (Palfique bond) and $8^{\text {th }}$ generation (Palfique universal bond) adhesive system results in less microleakage when compared to the $6^{\text {th }}$ generation (One up bond $\mathrm{F}$ plus) adhesive system.

The $8^{\text {th }}$ generation (Palfique universal bond) adhesive system has up to $50 \mathrm{MPa}$ micro-tensile bond strength to dentin, and has over $30 \mathrm{MPa}$ shear bond strength while $6^{\text {th }}$ generation (One up bond $\mathrm{F}$ plus) adhesive system has only $20 \mathrm{MPa}$ shear bond strength to dentin, which makes $8^{\text {th }}$ generation (Palfique universal bond) adhesive system more strong, durable and effective when compared to the $6^{\text {th }}$ generation (One up bond $\mathrm{F}$ plus) adhesive system. ${ }^{6,21}$

In the current study no-significant difference found between $6^{\text {th }}$ and $7^{\text {th }}$ generation adhesive systems, maybe due to the $7^{\text {th }}$ generation (Palfique bond) adhesive system having $20-25 \mathrm{MPa}$ tensile bond strength with up to $25 \mathrm{MPa}$ shear bond strength while $6^{\text {th }}$ generation (one up $\mathrm{f}$ plus bond) adhesive system having up to $20 \mathrm{MPa}$ bond strength in which there are not big differences between two generations in bond strength and since they both are light cured adhesive systems. ${ }^{6}$,

Results of this study showed that optimal degree of adhesion to tooth structure is still a challenge in restorative dentistry. Additionally the result of this research recommends the use of newer adhesive systems (Palfique universal bond, Tokuyama dentals). Further studies testing these materials in vivo are recommended to determine the potential clinical effect.

\section{Conclusion}

Based on the result of this study, the $8^{\text {th }}$ generation (Palfique universal bond, Tokuyama dentals) adhesive system shows a better marginal integrity in comparison to the $6^{\text {th }}$ generation (One up bond $\mathrm{F}$ plus) and $7^{\text {th }}$ generation (Palfique bond) adhesive system. In clinical bases use of $8^{\text {th }}$ generation adhesive system is recommended and 
clinical trials should be made in order to confirm its success in intraoral environment.

\section{Conflict of interest}

The authors reported no conflict of interests.

\section{References}

1. Zavattini A, Mancini M, Higginson J, Foschi $F$, Pasquantonio G, Mangani F. Micro-computed tomography evaluation of microleakage of Class II composite restorations: An in vitro study. Eur J Dent 2018; 12(3): 369-74. Accessed from: https:// doi.org/10.4103/ejd.ejd 2818

2. Somani R, Jaidka Sh, Arora S. Comparative evaluation of microleakage of newer generation dentin bonding agents: An in vitro study. Indian J Dent Res 2016; 27(1): 86-90. [cited 2019 Nov 4]. Available from: http://www.ijdr.in/text.asp? 2016/27/1/86/179837

3. Nair M, Paul J, Kumar S, Chakravarthy Y, Krishna $V$, Shivaprasad. Comparative evaluation of the bonding efficacy of sixth and seventh generation bonding agents: An In-Vitro study. J Conserv Dent 2014; 17(1): 27-30. [cited 2019 Nov 4]. Available from:

http://www.jcd.org.in/text.asp? 2014/17/1/27/124119

4. Sezinando A. Looking for the ideal adhesive - A review. Rev Port Estomatol Med Dentária E Cir Maxilofac 2014; 55(4): 194-206. https:// doi.org/10.1016/i.rpemd.2014.07.004

5. Rizvi S, Paul B, Mantri SP, Dube K, Agrawal A, Rana DP. Dentin Bonding Agents: An Overview. JDMS 2015; 14(11): 97-100.

6. Sofan E, Sofan A, Palaia G, Tenore G, Romeo U, Migliau G. Classification review of dental adhesive systems: from the IV generation to the universal type. Ann Stomatol (Roma) 2017; 8(1): 1-17. https://doi.org/10.11138/ads/2017.8.1.001

7. Yavuz I, Tumen EC, Kaya CA, Dogan MS, Gunay A, Unal $M$, et al. The reliability of microleakage studies using dog and bovine primary teeth instead of human primary teeth. Eur J Paediatr Dent 2013; 14 (1): 42-46.

8. Rengo C, Goracci C, Ametrano G, Chieffi N, Spagnuolo G, Rengo S, Ferrari M. Marginal Leakage of Class V Composite Restorations Assessed Using Microcomputed Tomography and Scanning Electron Microscope. Oper Dent 2015; 40: 440-448. Accessed from: https://doi.org/10.2341/14-022-L 9. Jacker-Guhr S, Ibarra G, Oppermann LS, Lührs AK, Rahman A, Geurtsen W. Evaluation of microleakage in class $\mathrm{V}$ composite restorations using dye penetration and micro-CT. Clin Oral Investig 2016;
20(7); 1709-1718. Accessed from: https:// doi.org/10.1007/s00784-015-1676-0

10. Al-Habdan AA. Review of microleakage evaluation tools. J Int Oral Health 2017; 9:141-5. Accessed from: [WWW Document]. URL http:// www.jioh.org/article.asp?issn=0976

11. Zanatta RF, Wiegand A, Dullin $C$, Borges $A B$, Torres CRG, Rizk M.

Comparison of micro-CT and conventional dye penetration for microleakage assessment after different aging conditions. Int J Adhes 2019; 89: 161-167.

\section{https://doi.org/10.1016/}

j.ijadhadh.2019.01.008

12. Parsa A, Ibrahim N, Hassan B, Motroni A, van der Stelt $P$, Wismeijer $D$. Influence of cone beam CT scanning parameters on grey value measurements at an Implant site. Dentomaxillofac Radiol 2013; 42(3). doi:10.1259/dmfr/79884780

13. Carrera CA, Lan C, Sanabria DE, Li Y, Rudney J, Aparicio C, Fok A. The Use of Micro-CT with Image Segmentation to Quantify Leakage in Dental Restorations. Dent Mater 2015; 31(4): 382-90.

14. Park JY, Chung JH, Lee JS, Kim HJ, Choi SH, Jung $\mathrm{SU}$. Comparisons of the diagnostic accuracies of optical coherence tomography, micro-computed tomography, and histology in periodontal disease: an ex vivo study. J Periodontal Implant Sci 2017; 47(1): $30-40$

15. Standardization IOF. ISO/Technical specifications 11405: Dentistry - Testing of adhesion to tooth structurel 2015

16. Poggio C, Chiesa M, Dagna A, Colombo M, Scribante $A$. Microleakage in class $V$ gingiva-shaded composite resin restorations. Ann stomatol 2012; 3(1): 19-23

17. Shetty $H$, Hegde $P$, Nadarsh $M H$, Shetty Sh, Shetty A. Evaluation of microleakage in composited with newer bonding systems by direct technique in class $V$ cavities: An in-vitro fluorescent dye penetration study. International research Journal of Pharmacy 2015; 6(2):161-163.

18. .Neves AA, Jaecques S, Van Ende A, Cardoso MV, Coutinho $E$, Lührs AK, et al. 3D-microleakage assessment of adhesive interfaces: Exploratory findings by $\mu C T$. Dent Mater. 2014;30:799-807.

$19 . \quad \mathrm{http} / / / w w w . t o k u y a m a-d e n t a l . c o m / t d c /$ bonding_agents/palfique_bond.html

20 Tsubota, Miyazaki et al. Nihon University the $145^{\text {th }}$ Meeting of the Japanese Society of Conservative Dentistry, 2016.

21. Katsumata, Sano et al. Kagoshima University ,Hokkaido University The $35^{\text {th }}$ Annual Meeting of Japan Society for Adhesive Dentistry, 2016.

22. http://www.tokuyamadental.com/tdc/pdf/ productsheet/

PALFIQUE UNIVERSAL BOND catalog.pdf 